\title{
An Analysis of Southern African Development Community (SADC) Free TradeArea (FTA): Implications for the Liquid Milk Consumers and Producers' Potential Welfare in Swaziland
}

\author{
Vulindlela S. Ginindza ${ }^{1}$, Francois I. Kabuya ${ }^{2}$ \\ INgwane Teachers'Training College,Swaziland \\ 2Agricultural Economics and Management Department, University of Swaziland, Swaziland
}

\begin{abstract}
Free Trade Area (FTA) is a regional integration agreement that removes tariffs among members, but leaves them with autonomy to set their tariffs with non-member countries. The Southern African Development Community (SADC) has launched its free trade area since 2008, but this process has remained a statement of intent for some member countries. This paper analyzed the SADC Free Trade Area-Implications for the Liquid Milk Consumers and Producers' Potential Welfare in Swaziland.Time series data for thirty-six years(19752010) were sourced from Food and Agriculture Organization (FAO), Swaziland Dairy Board (SDB), the Swaziland Central Statistics Office and Milk Producer Organization of South Africa. Data were analyzed using the partial equilibrium model to evaluate the welfare change; the log-regression models to estimate the price elasticities; and the error correction model to capturethe adjustment speed. Results show a potential positive net social welfare (198\% increase in market); the price elasticities of demand and supply are0.02 and 0.04, respectively and significant at 5 per cent $(p<0.05)$; and the error correction model $(E C M)$ is -0.62 . These results suggest that Swaziland should not only be committed to free trade agreement, but also to all regional integration processes in order to reap economic benefits from regional trade liberalization.
\end{abstract}

Keywords: Cointegration, free trade area, liberalization, Southern African Development Community, welfare

\section{Introduction}

Swaziland is a member of the Southern African Development Community (SADC), which was created in 1992 by the Treaty of Windhoek, replacing the Southern African Development Co-ordination Conference. Under the SADC Protocol on Trade implemented in year 2000, member countries agreed on reducing customs duties and other barriers to trade on imported products from each other for promoting economic growth and regional integration[1].

The SADC Free Trade Area (FTA)protocol was expected to create a regional market worth US\$ 360 billion with a total population of 170 million and economic growth of up to $7 \%$ per year on average. However, Swaziland's economic growth has been the least within the region [1].The purpose of this paper is to analyze the SADC FTA - Implications for the Liquid Milk Consumers and Producers' Potential Welfare in Swaziland. This paper is a welfare assessment of trade barriers on agriculture in a small country.

\subsection{Why is FTA Important?}

Reimer and Li [2]defined free trade area as a regional integration agreement that removes tariffs among members, but leaves them with autonomy to set their tariffs with non-member countries. Regional integration is a key vehicle for helping Africa to raise competitiveness, diversify its economic base and create enough jobs for its young and fast-urbanizing population [3].

In the SADC liberalization, agriculture is rated as a major player of the economy and estimated to contribute about $35 \%$ to the GDP, while about $70 \%$ of the people depend on it for food, income and employment [1].The main objectives of SADC FTA are to liberalize intra-regional trade in goods and services, ensure efficient production, contribute towards the improvement of the climate for domestic, cross-border trade and foreign investment and enhance economic development, diversification and industrialization of the region [4].

Some of the proposed strategies to achieve these objectives are (1) gradual elimination of tariffs, (2) adoption of common rules of origin, (3) harmonization of customs rules and procedures, and (4) elimination of non-tariff barriers and liberalization of tariff in services [1].This milestone on FTA is aimed at achieving a Custom Union and subsequently a SADC Common Market.

A number of studies looked at the free trade agreements. World Bank study indicates that regionalism in Africa can pool the under-utilized resources and fragmented markets, promote industrialization and act as a useful alternative to unilateral trade liberalization [5]. Burfisher, Robison and Thierfelder [6] argue that free trade reallocates factors of production to achieve structures of trade with their comparative advantages and with 
welfare gains arising from increased efficiency. Dao [7] suggestedthat global integration has helped countries to have access to and draw investment from the few regions of the world with the highest concentration in economic activity and purchasing power. He went on to argue that countries that limit the movement of goods, capital, people and ideas have in many decades experienced lower growth.Sarker and Jayasinghe [8] discuss that rapid spread of regional trade agreements brings the controversial welfare effects. The net welfare effects depend on the relative magnitude of trade creation and trade diversion effects, which varies across commodities within the same regional trade agreement.

\subsection{Trade Creation and Trade Diversion}

Trade creation occurs when some domestic production in a nation that is a member of the economic bloc is replaced by lower-cost imports from another member nation, assuming that all economic resources are fully employed before and after formation of the free trade area [4].Trade creation increases the welfare of member nations because it leads to greater specialization in production based on comparative advantage. Trade diversion occurs when lower-cost imports from outside the trade bloc are replaced by higher cost imports from a trade bloc member. Trade diversion reduces welfare, as production moves from efficient producers outside the bloc to less efficient producers inside the bloc [9].

\subsection{The Dairy Industry in Swaziland}

The dairy business started in the 1930s, by a Company collecting cream along the Manzini-Siteki road from beef herds. In the 1960s, production grew to 5.7 million litres of liquid milk from 4300 farmers (smallholder and larger farmers). The Dairy Act Number 28 established the Swaziland Dairy Boardin 1971. The Board's primary mandates are to develop and regulate the dairy industry in line with government goals of poverty reduction, food security, job creation, investment promotion and export promotion [10].

The consumption growth increased by $4 \%$ due to population growthwhile production grew at $2.5 \%$ per year on averagecreating furthershortage on the commodity [11]. The scarcity of feed resources, grazing resources in particular, volatile input costs such as fertilizer, grain concentrates, fuel cost and perpetual droughts exacerbated the milk shortage.

The traditional sector is derived from the local mixed multi-purpose breeds (usually beef herd), milked mostly during the summer months mainly after calving, when the grass is abundant and nutritious. Commercial sector refers to national dairy herd consisting of wide range of dairy breeds kept in Swazi Nation Land (SNL) and Title Deed Land (TDL), in small and medium-large scale production with the sole purpose of generating income. Table 1 shows the dairy herd statistics for the year 2007 in Swaziland for the four administrative regions [10].

Table 1 Dairy farms and dairy herd for year 2007.

\begin{tabular}{lllllll}
\hline Region & \multicolumn{2}{l}{ Number of dairy farmers } & \multicolumn{4}{c}{ Number of dairy cattle } \\
\cline { 2 - 7 } & SNL & TDL & Total & SNL & TDL & Total \\
\hline Lubombo & 66 & 8 & 74 & 313 & 80 & 393 \\
Manzini & 144 & 26 & 170 & 1003 & 1623 & 2626 \\
Shiselweni & 81 & 19 & 100 & 405 & 1065 & 1470 \\
Hhohho & 18 & 23 & 206 & 1011 & 580 & 1591 \\
\hline Total & 474 & 76 & 550 & 2732 & 3348 & 6080 \\
\hline
\end{tabular}

Source: [10] SDB 2009

Swaziland is one of the net importers of food in the SADC region. In dairy products alone, the country imports about 90\% worth E103 to E160 million per year to meet local consumer demand. On liquid milk equivalents, the domestic supply contributes only $15 \%$, while about $85 \%$ is imported [10]. The imported liquid milk is subject to tariff policy aiming at protecting the local producers.

\section{Literature Review}

Hartzeneberg [12] pointed out that Africa's integration record is marketed by grand schemes, weak legal and institutional foundations for a rules-based dispensation of regional integration, and an implementation record that does not demonstrate serious commitment.Sun and Reed [13] revealed that the creation of the SADC FTA increased agricultural exports to third-party countries and SADC was the only region that imported more from the third-party countries because of the multiregional and overlapping membership of the SADC region members. When a regional free trade area is implemented, less efficient sectors, like the dairy industry, benefit by allowing regional products to circulate freely.

Beghin and Sumner [14] argued that liberalization in dairy industry was expected to yield static welfare lossesand transfer in lower bound on the long-run magnitude and expected to induce dynamic gains in terms of productivity gains and larger choice via new products for consumers. There are negative effects of liberalization 
such as income losses from labour loss, lower wages from firms relocating production to lower-wage countries; the environmental damage increases with freer trade and some loss on sovereignty from the inevitable policy restrictions involved in trade agreement [15].

However, the World trade organization [16] reported several benefits from liberalization on human welfare such as improving employment opportunities and productivity, improving food supply and lowering food prices, and ensuring better access to health, education and information services.Studies carried to model change in liberalization of markets show significant decrease in world dairy prices, redistribution of milk production and trade among regions, and sizeable impacts on consumers and producers within reformed and other regions [11].

Bouamra and Requillart [17] assessed that proposed policy reforms in the European Union dairy sector were expected to increase the welfare marginally, but with large distributive effects.Sally [18] used ex-ante counterfactual analyses to the evaluation of regional integration agreements, based on partial or general equilibrium models, assuming a certain model structure, specific parameters, and functional forms to represent the participating economies are explicitly in the base year. The model is to simulate the preferential removal of tariffs; and welfare effects are calculated.

\subsection{Data}

\section{Methods}

The study used the time series data from 1975 to 2010,which were sourced from SDB, FAO, Milk Producer Organization of South Africa and the Swaziland Central Statistics Office.The domestic liquid milk supplied and demanded liquid milk, prices, world price, income per capita, tariffs and import permits are, in this study, the main variables.

\subsection{Data Analysis}

The study used demand and supply econometric models to estimate the price elasticities when implementing the protocol andthe simulated scenarios as well. Since many agricultural commodities reflect the Cobweb phenomenon [19], where supply reacts to price with lag of time period due to supply decisions taking time to implement; stationary and differencing are conducted on the data.

\subsubsection{Domestic Milk Demand Model}

The demand for liquid milk is function of price and income, assuming that other factors are not captured:

$\mathrm{Q}_{\mathrm{t}}=\mathrm{f}\left(\mathrm{P}_{\mathrm{t}}, \mathrm{I}_{\mathrm{t}}\right)$

$\log \mathrm{Q}_{\mathrm{t}}^{\mathrm{d}}=\mathrm{b}_{1}+\mathrm{b}_{2} \log \mathrm{P}_{\mathrm{t}}+\mathrm{b}_{3} \log \mathrm{I}_{\mathrm{t}}+\mathrm{u}_{\mathrm{t}(1)}$

Where:

$\mathrm{Q}_{\mathrm{t}}^{\mathrm{d}}=$ the total quantity of liquid milk demanded

$\mathrm{P}_{\mathrm{t}}=$ the domestic real price of milk

$I_{t}=$ the real income per capita

$\mathrm{U}_{\mathrm{t}}=$ the error term

\subsubsection{Domestic Milk Supply Model}

The quantity of liquid milk supplied is measured in tonnes and is function of lagged real price, while technology adoption is constant:

$\mathrm{Q}_{\mathrm{t}}^{\mathrm{s}}=\mathrm{f}\left(\mathrm{P}_{\mathrm{t}-1}\right)$

$\log \mathrm{Q}_{\mathrm{t}}^{\mathrm{s}}=\mathrm{b}_{1}+\mathrm{b}_{2} \log \mathrm{P}_{\mathrm{t}-1}+\mathrm{u}_{\mathrm{t}}$

Where:

$\mathrm{Q}_{\mathrm{t}}^{\mathrm{s}}=$ the total quantity of liquid milk supplied

$\mathrm{P}_{\mathrm{t}-1}=$ the lagged real price of liquid milk

$\mathrm{u}_{\mathrm{t}}=$ the error term

\subsection{Partial Equilibrium Analysis}

The partial equilibrium models are used in supply and demand of agriculture primary commodities excluding their processed forms [20]. This analysis assumes that the milk traded between the countries in the region is homogeneous and the market is perfectly competitive. It also assumes that the milk price is the farm gate price for both domestic supply and imported milk.

\subsubsection{Import Tariff and Import Quota Rate Analysis}

Fig. 1 below illustrates the equilibrium state of the quantity supplied and quantity demanded of liquid milk at the pre-trade price (PD) and the quantity (QE). The world price (PW) drives the demand from (QE) to (D2).The tariff increases price up to $(\mathrm{Pt})$ and reduces demand from $\mathrm{D} 2$ to $\mathrm{D} 1$, while supply moves to S2. The 
area $\mathrm{C}$ measures the government revenue from tariff or rent for import holders from quota rate, while the $\mathrm{A}$ and $\mathrm{D}$ areas represent the social cost or deadweight loss.

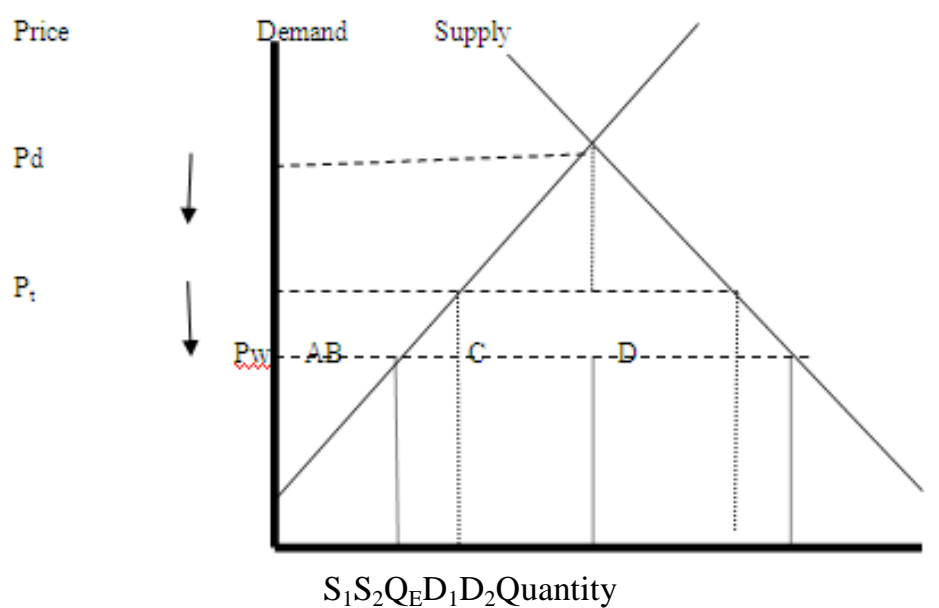

Fig. 1.The effect of a tariff on imports

Economic impact of the tariff on welfare is negative. Domestic consumers pay more for the liquid milk; they lose the sum of areas $(\mathrm{A}+\mathrm{B}+\mathrm{C}+\mathrm{D})$. This loss is partially offset by the gain that accrues to domestic producers from the higher price $(\mathrm{Pt})$ and the tariff revenue that is obtained by the Swazi government (equal to area $\mathrm{C}$ multiplied by the amount imported $(\mathrm{D} 1-\mathrm{S} 2)$. The net loss to the society due to the tariff is therefore equal to the sum of triangle areas $(B+D)$. These triangles reflect the distortion in resource allocation that the tariff creates; domestic producers produce too much (relative to free trade), and consumers consume too little.

\subsection{Cointegration and Error Correction Model}

The concept behind cointegration analysis is to verify if the group of time series variables usually of macroeconomics in nature do drift together. Engle and Granger [21] argued that, if nonstationarity or unit root exists and has the linear combination over time, then the variables are said to be cointegrated. Gujarati and Porter [19]stated that regression of nonstationary time series to nonstationary time series might produce a spurious regression.

The presence of a unit root in the error term can be determined using the following relationship:

$\Delta \mathrm{ut}=\alpha+\beta \mathrm{t}+(\rho-1) \mathrm{ut}-1+\sum \lambda \mathrm{i} \Delta \mathrm{ut}-\mathrm{I}$

Where $u_{t}$ is the residual series obtained from the regression of $\mathrm{Y}$ and $\mathrm{X}$. The ECM is a way of capturing adjustments in a dependent variable, which depends not on the level of the explanatory variable but on the extent to which the explanatory variable deviated from an equilibrium relationship with the dependent variable.

The ECM for the demand model is presented as show below:

$\Delta \mathrm{Q}=\delta_{0}+\delta_{1} \Delta \mathrm{P}_{\mathrm{t}}+\delta_{2} \Delta \mathrm{I}_{\mathrm{t}-1}-\lambda\left(\mathrm{Q}_{\mathrm{t}}-\partial_{0}-\partial_{1} \mathrm{P}_{\mathrm{t}-1}-\partial_{2} \mathrm{I}_{\mathrm{t}-1}\right)+\mathrm{v}_{\mathrm{t}}(4)$

Where $\delta$ measures the short-run effect on demand of a percentage change in own price and real income, that is, the short-run own price and real income elasticities of demand. The term inside the parenthesis provides the ECM and $\lambda$ is the error correction term.

The ECM provides the feedback effect or the adjustment effect, and shows how much of the disequilibrium is being corrected, that is, the extent to which any disequilibrium in the previous period affects any adjustment in the dependent variable. The error coefficient or adjustment coefficient tells us how much of adjustment to equilibrium takes place each period or how much of the equilibrium error is corrected [22].

\section{Results and Discussion}

Table 4.1shows the milk demand results. The price elasticity of demand for milk is 0.02 and the income elasticity is 0.03 , which are statistically significant at $1 \%(\mathrm{p}<0.01)$ and at $5 \%(\mathrm{p}<0.05)$, respectively. The results are consistent with the demand function behaviour as well as the consumer responsiveness in developing world with respect to income. 
Table 4.1 The demand function of liquid milk.

\begin{tabular}{lllll}
\hline Variable & Coefficient & S.E & t-statistics & Probability \\
\hline Constant & 10.474 & 0.03 & 349.133 & 0.000 \\
$\log \Delta \mathrm{I}$ & 0.027 & 0.006 & 4.515 & 0.0341 \\
$\log \Delta \mathrm{P}_{\mathrm{t}}$ & -0.016 & 0.007 & -2.232 & 0.0001 \\
\hline \multicolumn{2}{r}{$\mathrm{R}^{2}$ Adjusted $=0.60$} & & F-statistics $=10.827$
\end{tabular}

$\mathrm{R}^{2}=0.65$

$\mathrm{R}^{2}$ Adjusted $=0.60$

F-statistics $=10.827$

Table 4.2 is the milk supply results. The price elasticity is 0.04 and significant at $1 \%(\mathrm{p}<0.01)$. This shows that the quantity supplied is, subject to time constraint, likely to increase by $4 \%$ due to $10 \%$ change in price, ceteris paribus.

Table 4.2 The supply function of liquid milk.

\begin{tabular}{lllll}
\hline Variable & Coefficient & S.E & t-statistics & Probability \\
\hline Constant & 10.525 & 0.006 & 1848.169 & 0.000 \\
$\log \Delta \mathrm{P}_{\mathrm{t}-1}$ & 0.038 & 0.008 & 4.713 & 0.000 \\
\hline \multicolumn{5}{r}{$\mathrm{R}^{2}$ Adjusted $=0.74$} \\
\end{tabular}

Table 4.3 captures changes in demand for and supply of milk when SADC FTA is implemented. The partial equilibrium model predicts a decrease in quantity supplied and increase in quantity demanded as result of trade barriers removal. The results are consistent with the findings by Lariviere and Meilke [23]and OECD [24] that have shown a decrease in supply by high cost producers when the dairy industry was liberated, while low cost producers expanded their market.

Table 4.3 also indicates that liberating the dairy market would likely to improve consumers' milk accessibility by 50.5 tonnes at the same period through import tariff and import quotas $(198 \%$ increase in market). The milk consumers are likely to gain less from tariff, compared to quota rate. World trade organization [16] reported similar findings and argued that import quotas are more protective barriers when used to protect domestic markets.

Table 4.3 Expected changes in consumers' demand and producers' supply

\begin{tabular}{lllll}
\hline Changes & Tariff & \multicolumn{3}{c}{ Quota } \\
\cline { 2 - 5 } & Quantity (tonnes) & Percentage (\%) & Quantity (tonnes) & Percentage (\%) \\
\hline Consumer demand & 19.5 & 0.05 & 31 & 1.63 \\
Producer supply & 9.75 & 0.02 & 15.5 & 0.82 \\
\hline
\end{tabular}

Table 4.4 shows the error correction model (ECM) results. If the variables are cointegrated, then the residuals from the equilibrium regression can be used to estimate the error correction model that captures the speed of adjustment parameter. The model indicates the ECM is -0.62 that implies that $62 \%$ of the short run shocks may be adjusted back in the long run.

Table 4.4 Error Correction Model (ECM) Results

\begin{tabular}{ll}
\hline Variable & \multicolumn{1}{c}{ Short-run } \\
\hline Constant & $5.73(5.16)^{* *}$ \\
$\log \Delta$ Price & $-0.51(-2.01)^{*}$ \\
$\log \Delta$ Income & $0.79(2.62)^{*}$ \\
Residual & $-0.62\left(-3.59^{* *}\right.$ \\
$\mathrm{R}^{2}$ & 0.80 \\
F-statistics & 6.74 \\
\hline dicate significance at $5 \%$ and $10 \%$, respectively.
\end{tabular}

\section{Conclusion}

This paper assessed the welfare impact of trade barriers on the dairy industry in Swaziland, a small country, which is a net importer of foodstuffs. The analysis shows that the free trade agreement has a potential net positive welfare for the liquid milk market participants. This result is the same as that of Lariviere and Meilke [23], World trade organization [16] and organization for economic co-operation and development [24]. The paper implies that the removal of tariff and non-tariff barriers, especially in agriculture sector, may make a big difference in lives of people in Swaziland.

Swaziland is continually striking trade agreements with individual or groups of countries. The results of this paper should be considered, among other things, before the country commits to any change in trade policy. Although the paper is limited to one market, the welfare analysis may be extended to other sectors of the economy; and the Southern African Development Community regional integration investigation is left for future research. 


\section{References}

[1]. Southern African Development Community, free trade area handbook (Gaborone: Botswana, 2009).

[2]. J. Reimer, and M. Li, Trade costs and gains from trade in crop agriculture, American Journal of Agricultural Economics, 94(4), 1024-1039

[3]. Africa Competitiveness Report: World economic forum on Africa, Cape Town, South Africa, 2013

[4]. R. Sandrey, An analysis of the Southern development community free trade area,Trade and Law Centre, D13TB01, June 2013

[5]. S. Khorana, K. Kimbegwe, and N. Perdikis, The impact of tariff reductions underthe East African community customs union: Intratrade effects on Uganda, International Conference on Policy modelling, Sao Paul, Brazil, 2007

[6]. M. Burfisher, S. Robinson and K. Thierfelder, Regionalism: Old and new theory and practice: Where are we heading?International Conference: Agricultural policy reforms and the World trade organization, Capri, Italy, 2003

[7]. M.Dao, International integration and economic development, Journal Studies of Economics and Econometrics, 33(2), 2009 , 49-58.

[8]. R. Sarker, and S. Jayasinghe, Regional trade agreements and trade in agro-food products: Evidence for the European union from gravity modelling using disaggregated data, Agricultural Economics, 37(1), 2007, 93-104.

[9]. L. Yumei, International economics syllabus, Economics and Management School of Southwest University, Fall 2013

[10]. Swaziland Dairy Board, Annual report, Mbabane, Swaziland, 2009

[11]. FoodAgricultural Organization, Trade policy briefs on issues related to the

[12]. World trade organization negotiations on agriculture:Export Competition- AppropriateDisciplines for Eliminating Subsidies, issue No.4, Rome, Italy, 2004 [T. Hartzeneberg, Regional integration in Africa,Trade Law Centre for Southern Africa, October 2011

[13]. L. Sun, and M. Reed, M., Impacts of free trade agreements on agricultural: Trade creation and trade diversion,American Journal of Agricultural Economics, 92, 2010, 1351-1363.

[14]. J. Beghin, and D. Sumner, Dairy policy and trade: Content and Summary,Canadian Journal of Agricultural Economics, 47(6), 1999, 1-3.

[15]. R. Barichello, Broadening the North Atlantic free trade area: Key issues on the free trade area of the American from a Canadian perspective, Canadian Agricultural Economics Society and American Agricultural Economics Association, 49 (4), $2001,623-631$.

[16]. World Trade Organisation, A guide for officials legislators, civil society and allthose interested in international trade and global governance: Resource booklet for the $4^{\text {th }}$ WTO ministerial conference, Geneva, 2003

[17]. Z. Bouamra-Mechemache, R. Jongeneal, and V. Requillart, V., Impact of gradual increase in milk quotas on the EU dairy sector, European of Agricultural Economics, 35 (4), 2008, 461- 491.

[18]. R. Sally, Free trade agreements and the prospects for regional integration in East Asia,Asia Economic Policy Review, 1, 2006, 306321.

[19]. D.Gujarati, and D. Porter, Basic econometrics, $5^{\text {th }}$ edition (International Edition, New York: McGraw Hill, 2009)

[20]. F. Tongeren, H. Meijl, and Y. Surry, Global models applied to agricultural andtrade policies: A review and assessment, Agricultural Economics, 26, 2001,149-172.

[21]. R. Engle, and C. Granger, Cointegration and error correction: Representation, estimation and testing, Econometrica, 55(2), 1987, 251-276

[22]. D. Asteriou, and S. Hall S.G., Applied Econometrics: A modern approach using EViews and Microfit (New York: Palgrave Macmillan, 2007)

[23]. S. Lariviere, and K.Meilke, An assessment of partial dairy trade liberalization of the U.S., EU and Canada, Canadian Journal of Agricultural Economics, 47(5), 1999, 59-73

[24]. Organization for Economic Co-operation and Development, An analysis of dairy policy reform and trade Liberalization,Joint Working Party on Agriculture and Trade, OECD Report, 2004 